\title{
Drivers and consequences of apex predator diet composition in the Canadian
}

\section{Beaufort Sea}

Katie R.N. Florko, Gregory W. Thiemann, Jeffrey F. Bromaghin

K.R.N. Florko: ORCiD ID: 0000-0003-3829-7447. Department of Biology, York University, 4700 Keele Street, Toronto ON, M3J 1P3, Canada (katieflorko@gmail.com)

G.W. Thiemann: Faculty of Environmental Studies, York University, 4700 Keele Street, Toronto ON, M3J 1P3, Canada

J.F. Bromaghin: ORCiD ID: 0000-0002-7209-9500. Alaska Science Center, U.S. Geological Survey, 4210 University Drive, Anchorage AK, 99508, USA

Corresponding author: email: katieflorko@gmail.com, phone: 1-416-736-2100 x 227621

Author Contributions: KRNF and GWT conceived and formulated the ideas, KRNF processed tissue samples, KRNF and JFB analysed the data, KRNF and GWT wrote the manuscript, and JFB provided editorial advice and ecological insights. 


\section{Abstract}

2 Polar bears (Ursus maritimus) rely on annual sea ice as their primary habitat for hunting marine

3 mammal prey. Given their long lifespan, wide geographic distribution, and position at the top of

4 the Arctic marine food web, the diet composition of polar bears can provide insights into

5 temporal and spatial ecosystem dynamics related to climate-mediated sea ice loss. Polar bears

6 with the greatest ecological constraints on diet composition may be most vulnerable to climate-

7 related changes in ice conditions and prey availability. We used quantitative fatty acid signature

8 analysis (QFASA) to estimate the diets of polar bears $(n=419)$ in two western Canadian Arctic

9 subpopulations (Northern Beaufort Sea and Southern Beaufort Sea) from 1999 to 2015. Polar

10 bear diets were dominated by ringed seal (Pusa hispida), with interannual, seasonal, age- and

11 sex-specific variation. Foraging area and sea ice conditions also affected polar bear diet

12 composition. Most variation in bear diet was explained by longitude, reflecting spatial variation

13 in prey availability. Sea ice conditions (extent, thickness, and seasonal duration) declined

14 throughout the study period, and date of sea ice break-up in the preceding spring was positively

15 correlated with female body condition and consumption of beluga whale (Delphinapterus

16 leucas), suggesting that bears foraged on beluga whales during entrapment events. Female body

17 condition was positively correlated with ringed seal consumption, and negatively correlated with

18 bearded seal consumption. This study provides insights into the complex relationships between

19 declining sea ice habitat and the diet composition and foraging success of a wide-ranging apex

20 predator.

\section{Key words}

22 Foraging ecology, fatty acids, sea ice, climate change, polar bear

\section{Introduction}


24 Climate warming has contributed to rapid declines in sea ice extent, thickness, and seasonal

25 duration in the Arctic (Maslanik et al. 2011, Stroeve et al. 2012, Lindsay and Schweiger 2015).

26 Observed sea ice loss has occurred at a greater-than-forecasted rate, and declines are projected to

27 continue and accelerate through 2100 (Stroeve and Notz 2015, Wang and Overland 2015).

28 Although changes in sea ice conditions are well documented, the ecological consequences are

29 more difficult to assess and likely vary by region and over time (Wassmann et al. 2011, Stern

30 and Laidre 2016).

31 The response of a species to environmental change is often predicted by the relationship

32 of the organism with its habitat (Parmesan 2006). Quantifying habitat-demographic relationships

33 is often central to species management and conservation (e.g., Regehr et al. 2016). Apex

34 predators are top trophic-level organisms that influence the ecology of food webs (Katona and

35 Whitehead 1988, Horswill et al. 2016) and can serve as indicators of ecosystem change (Bowen

36 1997). Polar bears (Ursus maritimus) are apex predators with a wide geographical range, a long

37 lifespan, and may be particularly sensitive to climate-induced ecosystem change due to their

38 reliance on sea ice as a platform for hunting, travelling, and mating (Stirling and Derocher 1993;

39 Durner et al. 2017, Togunov et al. 2017, Lone et al. 2018). Long-term changes in sea ice

40 conditions have been associated with declines in polar bear body condition (Stirling et al. 1999,

41 Rode et al. 2010, Obbard et al. 2016), reproduction (Regehr et al. 2007, Rode et al. 2010),

42 survival (Regehr et al. 2007, Peacock et al. 2012) and abundance (Regehr et al. 2007, Bromaghin

43 et al. 2015, Lunn et al. 2016). The effects of declining sea ice on polar bear demography are

44 expected to be primarily mediated by changes in prey availability (i.e., spatio-temporal

45 distribution and abundance) leading to reduced foraging opportunities. 
Polar bears feed on a variety of marine mammal species throughout their range (Derocher

47 et al. 2002, Thiemann et al. 2008a). Studies suggest polar bears feed primarily on ringed seals

48 (Pusa hispida; Thiemann et al. 2008a), which have a wide distribution and high abundance

49 throughout the Canadian Arctic (Kingsley et al. 1985). Polar bears of most age classes and both

50 sexes are able to hunt ringed seals as they are the smallest Arctic seal (Kingsley et al. 1985).

51 However, ringed seals are dependent on sea ice for resting, molting, and building subnivian lairs

52 above breathing holes where they retreat to rear their pups (Smith and Stirling 1975), and are

53 thus vulnerable to climatic change (Ferguson et al. 2005, 2017, Ferguson and Higdon 2006,

54 Chambellant et al. 2012, Yurkowski et al. 2016, Reimer et al. 2019). During periods in the mid-

55 1970s and 1980s when heavy ice conditions in the Beaufort Sea were not favourable for ringed

56 seals to maintain breathing holes and birth lairs, the productivity and survival of both ringed

57 seals and polar bears declined (Stirling 2002). Given that polar bears may feed primarily on

58 newly weaned ringed seal pups (Stirling and Oritsland 1995), the proportion of ringed seal in

59 polar bear diets may reflect favourable environmental conditions for both species (Pilfold et al.

60 2015, Hamilton et al. 2017).

61 Although ringed seals are the primary prey of polar bears across the circumpolar Arctic,

62 bears also feed substantively on locally available prey, including bearded seals (Erignathus

63 barbatus; Thiemann et al. 2007, 2008a), harp seals (Pagophilus groenlandica; Derocher et al.

64 2002, Galicia et al. 2015), harbour seals (Phoca vitulina; Thiemann et al. 2008a, Sciullo et al.

65 2017), walruses (Odobenus rosmarus; Calvert and Stirling 1989), beluga whales

66 (Delphinapterus leucas; Freeman 1973), narwhals (Monodon monoceros; Smith and Sjare 1990),

67 and the carcasses of bowhead whales (Balaena mysticetus; Bentzen et al. 2007, Schliebe et al.

68 2008, Herreman and Peacock 2013, Galicia et al. 2016, Lillie et al. 2019). The relative 
69 importance of alternative prey (i.e., other than ringed seal) may vary both spatially and

70 temporally according to sea ice conditions (Hamilton et al. 2017, Boucher et al. 2019), prey life

71 history (Young et al. 2015) and seasonal habitat use (Hornby et al. 2017). Polar bear diet may

72 also vary within a subpopulation due to differences in body size and energetic requirements.

73 Adult male polar bears are approximately twice the size of adult females (Derocher et al. 2005),

74 which confers higher energetic demands but also allows them to hunt larger prey species (e.g.,

75 bearded seals; Thiemann et al. 2007, 2008a, Derocher et al. 2010).

77 demographic decline, with estimated abundance falling 25-50\% from 2004 to 2006 followed by a

78 period of stability through 2010 (Bromaghin et al. 2015). In contrast, the adjacent Northern

79 Beaufort Sea subpopulation remained largely stable through the mid-2000s (Stirling et al. 2011).

80 The ecological drivers of these divergent demographic trends are not well understood, although

81 the decline in Southern Beaufort Sea was hypothesized to be driven by reduced sea ice in

82 summer and increased sea ice deformation in winter, which may have negatively affected the

83 ability of polar bears to access their prey (Bromaghin et al. 2015).

84 The fatty acid (FA) composition of a predator's adipose tissue reflects its diet over the

85 preceding weeks to months, as ingested FA are predictably incorporated into a consumer's fat

86 stores (Ackman and Eaton 1966, Iverson et al. 2004, Budge et al. 2006, Thiemann et al. 2008a,

87 2008b). Quantitative fatty acid signature analysis (QFASA; Iverson et al. 2004) models the FA

88 profile or "signature" of an individual predator as a linear combination of potential prey

89 signatures. QFASA estimates diet composition by determining the relative proportion of

90 different prey types that minimizes the distance between the observed and modeled predator

91 signature after accounting for FA-specific patterns of metabolism (Iverson et al. 2004). 
As energy is stored in adipose tissue, the proportion of lipid (relative to non-lipid

93 components) will increase (Pond 1992). Conversely, when energy is mobilized, relative lipid

94 content will decline. Thus, the relative lipid content of adipose tissue can serve as an indicator of

95 body condition in polar bears (Thiemann et al. 2006, McKinney et al. 2014, Sciullo et al. 2016).

96 We used lipid analyses and QFASA to quantify the diet composition and body condition

97 of polar bears harvested in the Canadian Beaufort Sea from 1999 to 2015, a period of substantial

98 habitat and demographic change. Our objective was to examine environmental drivers of diet

99 composition, in addition to spatial, temporal, and age- and sex-specific variation, and the

100 implications on body condition. We hypothesized that polar bear diet composition and body

101 condition would be affected by regional sea ice conditions, resulting in differences in diet and

102 foraging success (i.e., body condition) over time. We further hypothesized that differences in diet

103 and body condition across bears of different age classes and sexes would result from the ability

104 of adult males to capture larger-bodied prey. A better understanding of the relationship between

105 sea ice habitat and the diet composition and foraging success of top predators will allow more

106 accurate predictions of the ecological effects of future climate warming.

\section{Material and Methods}

\section{Sample Collection}

109 We used adipose tissue samples collected from 419 polar bears harvested by hunters in the

110 Inuvialuit Settlement Region of the Canadian Beaufort Sea from 1999 to 2015. Bears belonged

111 to two recognized subpopulations: Northern Beaufort Sea and Southern Beaufort Sea, with the

112 subpopulation boundary established by the Northwest Territories and Yukon Territory (Fig. 1).

113 However, because the majority of samples (89\%) came from the Northern Beaufort Sea and

114 bears in the Southern Beaufort Sea were sampled close to the management unit boundary (Fig. 
115 1), we did not use subpopulation as a factor in our models. It is illegal to harvest adult females

116 with dependent offspring so sampled bears included males and solitary females of independent

117 age classes (Table S1; defined as: adults $=5+$ years old; subadults $=3-4$ years old). Age was

118 determined by counting growth layer groups in the cementum of an extracted vestigial premolar

119 (Calvert and Ramsay 1998). For seasonal analyses, we defined winter/spring as January - June

120 and summer/fall as July - December; sampling in the winter/spring was primarily from February

121 - May, and sampling in summer/fall was primarily in November. Samples of subcutaneous

122 adipose tissue (approx. $8 \mathrm{~cm} \mathrm{x} 4 \mathrm{~cm}$ ) were collected from each bear and individually wrapped in

123 aluminum foil, sealed in a Whirl-Pak, and stored at $-20^{\circ} \mathrm{C}$ until analysis.

124 Other recent work has used QFASA to examine the diets of polar bears in the adjacent

125 Chukchi Sea subpopulation, so to make our results comparable for future studies, we used the 126 prey FA library from Bromaghin et al. (2017) which included ringed seals $(\mathrm{n}=23)$, bearded seals $127(\mathrm{n}=83)$, beluga whales $(\mathrm{n}=29)$, and bowhead whales $(\mathrm{n}=64)$. We included additional blubber 128 samples from 248 ringed seals harvested by Inuvialuit hunters in the eastern Amundsen Gulf for 129 a total prey library of 447 individual animals. As with polar bear adipose tissue, marine mammal 130 blubber was sampled from skin to muscle, wrapped in aluminum foil, sealed in a Whirl-Pak, and 131 stored at $-20^{\circ} \mathrm{C}$ until analysis.

\section{Laboratory Analyses}

133 We subsampled the interior of polar bear adipose tissue and marine mammal blubber samples

134 (approx. $0.3 \mathrm{~g}$ ) to avoid any oxidized tissue (Budge et al. 2006). Tissue subsamples were

135 weighed and lipid was quantitatively extracted using a modified Folch extraction (Folch et al.

136 1957, Iverson et al. 2001). Lipid content was expressed as the percent of total sample wet weight

$137 \pm 1$ standard error and used as an index of body condition (Thiemann et al. 2006, McKinney et 
138 al. 2014, Sciullo et al. 2016). FA methyl esters (FAME) were derived from the extracted lipid 139 using sulfuric acid in methanol as a catalyst (Thiemann et al. 2004; Budge et al. 2006). FAME

140 were analyzed in duplicate on a temperature-programmed gas chromatograph (GC) with a flame 141 ionization detector fitted with a polar column (30 m x $0.25 \mathrm{~mm}$ inner diameter; DB-23; Agilent 142 Technologies, Palo Alto, California, USA; Budge et al. 2006). FA were measured as mass

143 percent of total FA \pm 1 standard error, and expressed by the shorthand nomenclature of $A: B \mathrm{n}-X$, 144 where $A$ is the length of the carbon chain, $B$ is the number of double bonds, and $X$ is the position 145 of the first double bond relative to the terminal methyl group. FA identifications were based on 146 retention times and were manually verified and corrected using CompassCDS software (Version 147 3.0, Bruker Daltonics Inc., Germany).

\section{$148 \quad$ QFASA Modelling}

149 The QFASA method developed by Iverson et al. (2004) generates estimates of predator diets by 150 modelling the predator signature as a linear combination of available prey signatures and 151 determining the combination of prey that minimizes the distance between the observed and 152 modelled predator. Calibration coefficients derived from captive mink (Neovison vison;

153 Thiemann et al. 2008b) were used to account for FA-specific patterns of modification and 154 biosynthesis that occur within the predator (Iverson et al. 2004). We generated estimates of diet 155 composition for each polar bear using the est_diet function in the R package qfasar (distance 156 measure: Aitchison; estimation space: prey; Bromaghin 2017). We also used a new diagnostic 157 function to generate a jackknifed cross-validation of the prey library: leave-one-prey-out (LOPO; 158 function: lopo()). LOPO temporarily removes each prey sample from the prey library and models 159 its diet estimate, as if it were a predator, before returning it to the prey library. This was done for 160 each prey sample, and means were calculated for each type (i.e., species), which yields a 
161 measure of the prey types' distinctiveness within the library. To determine the suite of FA to use

162 in QFASA modelling, we started with the dietary set used by Galicia et al. (2015) and removed

163 each FA in turn, ran the LOPO analysis, and investigated the accuracy of prey classifications.

164 LOPO outputs the mean distribution of estimates among all prey types; perfect estimation yields

165 values of 1 for each prey type (Bromaghin 2017). If LOPO analysis showed more accurate (i.e.,

166 higher) values upon FA removal, we removed the respective FA from QFASA diet estimations.

167 QFASA diet estimation and diagnostics were conducted using R (version 3.4.0, GUI 1.40, R

168 Development Team 2017).

\section{Sea Ice Data}

170 We used sea ice data from the National Snow and Ice Data Center (NSIDC; Boulder, CO), as

171 summarized by Stern and Laidre (2016). Although Stern and Laidre (2016) used the previous

172 Northern-Southern Beaufort subpopulation boundary at $125^{\circ} \mathrm{W}$ (see Durner et al. 2018), which

173 was slightly east of the updated boundary used in this study $\left(133^{\circ} \mathrm{W}\right.$; Fig 1$)$, the methods of

174 Stern and Laidre (2016) still reflect regional sea ice conditions in the two subpopulations. Daily

175 sea ice data were measured by satellites Nimbus-7 SSM and DMSP SSM/I-SSMIS Passive

176 Microwave Data at a cell size of 25 x $25 \mathrm{~km}$ daily. Stern and Laidre (2016) derived yearly values

177 for four sea ice metrics in Southern Beaufort Sea and Northern Beaufort Sea: date of sea ice

178 break-up, date of sea ice freeze-up, duration of open water season, and mean summer sea ice

179 concentration. A threshold for each year was calculated as the mid-point between the March

180 mean sea ice concentration and the September mean sea ice concentration. Date of sea ice freeze-

181 up and date of sea ice break-up were calculated as the day of year that sea ice concentration

182 crossed above or below the year's threshold, respectively. Duration of the open water season was 
183 calculated as the number of days between sea ice break-up and freeze-up. Mean summer sea ice

184 concentration was calculated for 1 June - 31 October for each year.

\section{Statistical Analyses}

186 We used a redundancy analysis (RDA; van den Wollenberg 1977) and a forward-

187 selection model to examine the minimum number of variables that significantly influence polar

188 bear diet, and ranked the models (i.e., each successive step in the forward selection model as it is

189 building) using Akaike information criterion (AIC) to identify variables that explained the most

190 variation in the response variables (Borcard et al. 1992). The RDA included all intraspecific

191 (age, age class, sex), spatial (longitude, latitude), temporal (ordinal date, month, season, year),

192 and environmental (sea ice break-up, freeze-up, duration of open-water season, mean summer

193 sea ice concentration) predictor variables. Prior to RDA modelling we transformed the diet data

194 (response variables) using the Hellinger transformation, which takes the square root of the sum

195 of each proportion per prey species, reducing skewedness of more prominent response variables

196 (i.e., ringed seal proportion in diet estimates; Legendre and Gallagher 2001).

197 Results from the RDA indicated which variables were driving polar bear diet; we further

198 analyzed differences between significant binary variables (i.e., sex, season) using permutation

199 MANOVA (for overall diet) and permutation one-way ANOVA (for individual prey types'

200 contribution to bear diet), as diet estimates were proportional and therefore not normally

201 distributed. We tested for age-, longitudinal-, and year-effects using Spearman rank correlations

202 for each species' contribution to polar bear diet, when separated by sex. We also used Spearman

203 rank correlations to examine the relationship between polar bear diet and body condition (i.e.,

204 percent lipid in the adipose tissue) independently for each prey type. 
Temporal trends in sea ice metrics were tested using linear regression. The relationship

206 between each sea ice metric and the proportion of each prey in polar bear diets was also tested in

207 a linear regression, separated by sex; Southern Beaufort Sea bears were not included due to small

208 sample size in some years (Table S1). Similarly, we used linear regression to investigate the

209 relationship between sea ice and body condition of bears separated by sex. Since bears harvested

210 in the winter/spring were mostly killed in February-March, their foraging would not be

211 influenced by the date of sea ice break-up, freeze-up, duration of the open water season, or

212 summer sea ice concentration of that year; thus, winter/spring bears were compared against the

213 sea ice break-up, freeze-up, duration of open water season, and summer sea ice concentration in

214 the year prior to sampling. All statistical analyses were conducted using R (version 3.4.0, GUI

215 1.40, R Development Team 2017).

216 Results

217 QFASA Modelling Diagnostics

218 LOPO analysis revealed the clearest separation between prey FA signatures when FA 22:1n-9

219 was omitted. LOPO allocation accuracy for the final set of 29 FA was 0.92 for bearded seal and

220 beluga whale, 0.97 for bowhead whale, and 0.86 for ringed seal, thus, $22: 1 \mathrm{n}-9$ was excluded

221 from QFASA diet estimations.

\section{General Dietary Patterns}

223 The mean $( \pm$ SE) diet composition of all polar bears harvested in the Beaufort Sea was $15.1 \pm$

$2240.9 \%$ bearded seal, $17.8 \pm 0.8 \%$ beluga whale, $10.0 \pm 0.4 \%$ bowhead whale, and $57.1 \pm 0.9 \%$

225 ringed seal. Polar bear diets were dominated by ringed seals irrespective of bear sex, season, or

226 age class. 
228 influencing polar bear diet (Table $1 ; p=0.002)$. In the forward-selection, models including sex,

229 and combining sex and age were considered the second and third best fitting models;

230 additionally, date of sea ice freeze-up and break-up, and year were also significant covariates

231 (Table 1).

\section{Spatial Patterns}

233 Longitude of sampling location, of all single variables, explained the most variation in diet

234 composition (Table 1). For male bears, but not females, the proportional consumption of every

235 prey type differed with longitude. Male bears' consumption of bearded seal $(\rho=-0.352, S=$

$2363738400, p<0.001)$ and bowhead whale $(\rho=-0.150, S=3177400, p=0.017)$ decreased, and

237 beluga whale $(\rho=0.349, S=1800200, p<0.001)$ and ringed seal $(\rho=-0.137, S=2384300, p=$

238 0.028) increased, as sample location moved from west (e.g., Tuktoyaktuk Peninsula, western

239 Banks Island) to east (e.g., Amundsen Gulf; Fig. 1, S1).

\section{Intraspecific Patterns}

241 Polar bear diet composition differed between males and females $(p=0.001)$; males consumed

242 proportionately more bearded seal $(p<0.001)$ and less ringed seal than females $(p<0.001)$, but

243 there was no difference between male and female consumption of beluga or bowhead whale ( $p=$

$2440.961, p=0.345$, respectively). Male polar bears also differed between age classes $(p=0.001)$ in

245 their consumption of bearded seal ( $p<0.001$, adults highest), beluga whale $(p=0.012$, adults

246 highest), and ringed seal ( $p<0.001$, subadults highest), but not bowhead whale $(p=0.216)$.

247 Specifically, the proportional consumption of bearded seal increased with the age of male bears

248 (Fig. 2; $\rho=0.401, S=1965212, p<0.001$ ), whereas ringed seal consumption decreased with age 
$249(\rho=-0.387, S=4550832, p<0.001)$. There were no significant trends between age and the

250 consumption of any prey type for females.

251 Seasonal Trends

252 Polar bear diets differed between the summer/fall and winter/spring (Fig. $3 ; p=0.014$ ). In

253 females, bearded seal consumption was higher $(p=0.001)$ and beluga whale was lower in the

254 summer/fall $(p=0.033)$ relative to winter/spring. Bowhead whale and ringed seal consumption

255 was not significantly different between seasons ( $p=0.298, p=0.902$ respectively). Male polar

256 bears consumed the same amount of bearded seal, bowhead whale, and ringed seal in the

257 summer/fall and winter/spring $(p=0.745, p=0.321, p=0.863$, respectively). Beluga whale

258 contributed more to the diet of male polar bears in the winter/spring than the summer/fall $(p=$ $2590.003)$.

\section{Body Condition and Diet}

261 Body condition did not differ between sexes $(p=0.263)$ or age classes $(p=0.181)$. There was a

262 positive correlation between ringed seal consumption and body condition $(\rho=0.206, S=$

$263347780, p=0.016$ ), and a negative correlation between bearded seal consumption and body

264 condition $(\rho=-0.169, S=511840, p=0.048)$ in female polar bears. We found no relationship

265 between proportional diet composition and body condition in male bears (Table S2).

\section{Temporal Trends}

267 Ringed seal remained the primary prey of polar bears in all years, for both males and females,

268 with interannual variation (Fig. 4). Beluga whale consumption was higher in congruent years

269 when ringed seal consumption was reduced. Overall, we found no directional change in the

270 consumption of any prey type over time. 


\section{$271 \quad$ Sea Ice}

272 Sea ice freeze-up in both the Northern Beaufort Sea and Southern Beaufort Sea subpopulation

273 zones occurred progressively later in the year and the duration of open water increased over the

274 course of our study (1999-2015). Moreover, sea ice break-up occurred progressively earlier and

275 summer sea ice concentration declined over the study period in Southern Beaufort Sea but not

276 Northern Beaufort Sea (Fig. 5).

277 Sea ice freeze-up and summer sea ice concentration had no significant effect on polar

278 bear diet in Northern Beaufort Sea (Table S3). For female bears, sea ice break-up was positively

279 related to the proportion of beluga whale (i.e., later break-up associated with higher beluga; Fig.

$2806 ; F=7.600, R^{2}=0.398, p=0.022$ ), without significantly reducing the proportion of other prey

281 in the diet. Correlations between the date of spring break-up and consumption of bowhead whale

282 and ringed seal were non-significant but trended negative (Table S3). The diets of male bears

283 were not related to any of the sea ice metrics (Table S3).

284 Sea ice dynamics were significantly related to the body condition of female polar bears in

285 Northern Beaufort Sea, where shorter duration of the open-water season $\left(F_{1,11}=7.219, R^{2}=\right.$

$2860.341, p=0.021)$, and later dates of sea ice break-up $\left(F_{1,11}=11.63, R^{2}=0.470, p=0.006\right)$, were

287 positively related to body condition (Fig. 7). Additionally, there was a non-significant positive

288 trend between summer ice concentration and body condition $\left(F_{1,11}=3.769, R^{2}=0.188, p=\right.$

289 0.078), and no effect of the date of fall freeze-up on female body condition (Fig. $7 ; F_{1,11}=0.557$,

$\left.290 R^{2}=-0.038, p=0.471\right)$. Conversely, the body condition of male polar bears in Northern Beaufort

291 Sea was not affected by the summer ice concentration $\left(F_{1,11}=0.385, R^{2}=-0.054, p=0.547\right)$, the

292 duration of the open-water season $\left(F_{1,11}=0.217, R^{2}=-0.070, p=0.650\right)$, the date of fall freeze- 
293 up $\left(F_{1,11}=0.601, R^{2}=-0.034, p=0.455\right)$, or the date of spring break-up $\left(F_{1,11}=0.004, R^{2}=-\right.$

$2940.091, p=0.950)$.

\section{Discussion}

296 As top predators reliant on annual sea ice habitat, polar bears and their foraging habits can 297 provide insights into the ecological effects of climate warming. Our results reveal relationships

298 between sea ice conditions, polar bear diet, and foraging success in a region undergoing rapid sea

299 ice decline. Sea ice loss was associated with lower body condition among female polar bears

300 suggesting reduced foraging success. The demonstrated differences in diet composition and

301 response to habitat conditions among age and sex classes suggests that some bears (i.e., adult

302 males) are better equipped to cope with changes in prey availability and habitat quality. Greater

303 constraints on the dietary options for juvenile and female bears make them more susceptible to

304 demographic consequences in the western Canadian Arctic.

\section{Spatial Patterns}

306 Of all the variables separately, the longitude of harvest location explained the most variation in

307 polar bear diet (Table 1), specifically for male bears. Male bears consumed relatively more

308 bearded seal and bowhead whale in the west portion of the study area, and more beluga whale

309 and ringed seal in the east, patterns that are likely consistent with prey abundance: bearded seals

310 primarily reside in the offshore pack-ice and may be in greater abundance in the Beaufort and

311 Chukchi Seas than in Amundsen Gulf (Smith 1980, Quakenbush et al. 2011), and a greater

312 abundance of ringed seal is supported in Amundsen Gulf than the Beaufort and Chukchi Seas

313 (Harwood and Kingsley 2013, Pilfold et al. 2014, Harwood et al. 2015). Amundsen Gulf is also

314 an important ringed seal pupping area (Harwood et al. 2000, 2012). Greater proportions of

315 bowhead whale in the western portion of the study area is consistent with access to subsistence- 
316 harvested bowhead whale carcasses along the Alaska coast (Ashjian et al. 2010, Herreman and

317 Peacock 2013).

318 Bears may have had access to beluga whales as they migrated from the Bering Sea to the

319 Beaufort Sea in spring; whales move adjacent to the landfast ice over the Mackenzie Shelf and

320 into Amundsen Gulf in early June (Harwood and Smith 2002), further aggregate in the

321 Mackenzie Estuary when the landfast ice breaks up (Huntington et al. 1999, Harwood and Smith

322 2002, Luque and Ferguson 2009, Hornby et al. 2016) and disperse offshore across the Mackenzie

323 Shelf in late July/August (Harwood and Kingsley 2013). Since our results suggest male polar

324 bears consumed greater proportions of beluga whale in Amundsen Gulf than the western portion

325 of the study area (i.e., Mackenzie Estuary), there may be more polar bear foraging opportunities

326 on beluga whale during their Mackenzie Estuary shoulder seasons. In contrast to males, female

327 polar bears showed no spatial structure in their diet composition, possibly as a consequence of

328 shared feeding areas, such as around the Cape Bathurst Polynya (Thiemann et al. 2008a). Our

329 results of female foraging on ringed seals throughout the study area are consistent with kill-sites

330 recorded by Pilfold et al. (2014) who observed ringed seal kill-sites along the landfast ice along

331 the Tuktoyaktuk Peninsula Region, western Banks Island, and in the Amundsen Gulf.

\section{Intraspecific Patterns}

333 Variability in polar bear diet between sexes and age classes may be due to differences in hunting

334 ability, energetic requirements, and spatial segregation. Our results are consistent with previous

335 studies (e.g., Cherry et al. 2010, McKinney et al. 2017, Thiemann et al. 2008a) that suggest

336 female polar bears are more reliant on ringed seals than are males, which forage more on bearded

337 seals. Females with dependent cubs may focus their hunting on ringed seals on the landfast ice,

338 thus limiting spatial overlap with potentially infanticidal adult male bears, which may hunt in the 
339 offshore pack ice where bearded seal densities are higher (Smith 1980, Quakenbush et al. 2011).

340 The large size of adult male bears allows them to potentially hunt large-bodied prey, like adult

341 bearded seals, more easily (Cherry et al. 2010, Derocher et al. 2005, 2010). Solitary adult

342 females, and subadult bears of both sexes, may have access to bearded seal pups and be able to

343 scavenge on remains from adult bearded seal kills made by adult male polar bears.

344 We found males consumed proportionately more bearded seal with age (Fig. 2), likely

345 due to increasing body mass, as male polar bears continue to grow well after sexual maturity

346 (Derocher et al. 2010). Thiemann et al. (2007) documented a positive correlation between adult

347 male body mass and bearded seal consumption. The clear age-driven shift away from ringed seal

348 and towards bearded seal in male polar bears may serve to reduce intraspecific competition with

349 adult females and juvenile bears, which are more dependent on ringed seal.

\section{Body Condition and Diet}

351 Body condition of female bears was positively correlated with the consumption of ringed seal

352 and negatively correlated with bearded seal consumption (Table S2). These patterns suggest that

353 female bears experience declining body condition when preferred ringed seal prey are less

354 available and rely more heavily on scavenging the carcasses of large bodied prey (i.e., bearded

355 seals). The lack of relationship between body condition and diet in male bears may be a

356 consequence of greater dietary flexibility in male bears and their ability to exploit bearded seals

357 as a widely available prey.

$358 \quad$ McKinney et al. (2017) examined bears in the western portion of the Southern Beaufort

359 Sea and found a positive correlation between body condition and bowhead whale consumption, a

360 pattern not detected in our results from the Canadian Beaufort Sea. These different spatial

361 patterns are likely related to the distribution of bowhead carcasses, which are concentrated 
362 around the communities of Kaktovik, Nuiqsut, and Utqiagvik, AK (McKinney et al. 2017, Lillie

363 et al. 2019). Our results suggest that Alaskan bowhead harvests have not measurably influenced

364 the foraging ecology of polar bears in the Canadian Beaufort Sea.

\section{Seasonal and Interannual Trends}

366 Seasonal differences in diet composition suggest that polar bears feed on seasonally available

367 prey, particularly increased beluga whale consumption in the winter/spring, similar to the

368 findings of McKinney et al. (2017). Predation on beluga whale is presumably related to whale

369 migration, which is dependent on sea ice conditions (Huntington 2002, Hornby et al. 2016).

370 Forecasted sea ice trends may allow for the timing of beluga migration to occur progressively

371 earlier in the winter/spring providing an important food source for polar bears in the Canadian

372 Beaufort Sea.

373 Diet composition varied across years for all age classes and sexes, suggesting interannual

374 variation in prey availability. Female bears consumed proportionately more beluga whale in

375 years when ringed seal was reduced, and more ringed seal when beluga whale was reduced,

376 while bowhead whale and bearded seal did not appear to be related to other prey. Our results

377 suggest beluga whale is an important secondary prey source for both male and female polar bears

378 in our study area. The low ringed seal consumption for all bears in 2007 , and female bears in

3792010 (Fig. 4), suggest a possible decrease in ringed seal availability in those years. Summer

380 Arctic sea ice extent reached a record minimum in 2007 (Wood et al. 2013); potentially

381 inhibiting the ability of ringed seals to produce pups and for polar bears to forage effectively.

382 Low ringed seal consumption and low body condition of polar bears in 2007 is consistent with

383 our hypothesis that reduced sea ice would result in a decrease of polar bear foraging on ringed

384 seals, and increased reliance on alternative prey, such as beluga whale (Fig. 4). Recent climatic 
and oceanographic changes, particularly in the Beaufort Sea, such as increased upwelling of

386 nutrients and an increase in pelagic marine productivity along the Beaufort slope (Schulze and

387 Pickart 2012, Pickart et al. 2013), may offer favorable foraging conditions for beluga whales

388 (Harwood and Kingsley 2013). More generally, Harwood and Kingsley (2013) report an increase

389 in beluga whale abundance in the offshore Beaufort Sea in late August in 2007-2009 relative to

390 the mid-1980s.

$391 \quad$ Hornby et al. (2014) conducted beluga whale aerial surveys over the Mackenzie River

392 estuary and the Tuktoyaktuk Peninsula from 2011-2013, and found relatively low abundance of

393 beluga in 2011 (23 whales; possibly due to logistical effects of poor weather), higher abundance

394 in 2012 (270 beluga observed on the day of ice break up; similar to surveys done in the 1970s

395 and 1980s), and relatively high beluga density in 2013 (305 whales observed the day after ice

396 break-up). Our estimates of beluga whale consumption by polar bears (Fig. 4) are not consistent

397 with these patterns of whale abundance, suggesting that years with comparatively higher

398 numbers of beluga in the Mackenzie River estuary and near the Tuktoyaktuk Peninsula are not

399 necessarily years polar bears are able to forage on more beluga whale. Rather, consumption of

400 beluga appears to be more strongly affected by regional sea ice conditions (see below). Overall,

401 our results suggest higher polar bear consumption of beluga whale than previously documented

402 in the region (Thiemann et al. 2008a, Rode et al. 2014, McKinney et al. 2017).

\section{Sea Ice Trends and Foraging Dynamics}

404 Sea ice freeze-up occurred progressively later in the year, and subsequently the duration of the 405 open water season increased over the study period (Fig. 5). However, these long-term declines in 406 sea ice conditions were not matched by similar trends in polar bear diet composition in Northern 407 Beaufort Sea, which showed interannual variability that was not consistently driven by sea ice 
408 conditions. However, later ice break-up (that is, "heavy" sea ice conditions) was correlated with

409 higher beluga whale consumption. Heavy spring ice may delay beluga movements into, and out

410 of, summer feeding areas, which may result in beluga entrapments during fall freeze-up in the

411 Southern Beaufort Sea (Higdon and Ferguson 2012). Thus, our results suggest spring sea ice

412 conditions are a driver of beluga whale consumption and are potentially indicative of polar bears

413 foraging on beluga whales at entrapment events. The trend toward high beluga whale

414 consumption at both heavy sea ice conditions may also be inversely related to ringed seal

415 productivity, which may be reduced at heavy sea ice conditions (see below and Stirling 2002).

416 The positive relationship between date of spring ice break-up and body condition of

417 female bears in Northern Beaufort Sea adds to the growing body of evidence that increased time

418 on-ice in the spring is linked to higher foraging success and improved nutritional status (see

419 Stirling et al. 1999, Rode et al. 2010, Obbard et al. 2016). The negative relationship between

420 duration of open-water season and body condition also suggests on-ice foraging is essential for

421 the nutritional health of female polar bears. In contrast to female bears, male bears showed no

422 relationships between sea ice conditions and body condition (or diet), possibly indicative of their

423 flexible diet and ability to exploit larger-bodied prey. Although the trend was not significant, we

424 found evidence of reduced ringed seal consumption by Northern Beaufort Sea bears in years with

425 delayed sea ice break-up. Heavy spring sea ice conditions have reduced the reproductive success

426 of Beaufort Sea ringed seals in the past (Stirling 2002) and may limit the ability of polar bears to

427 prey on newly weaned ringed seal pups (Bromaghin et al. 2015). Thus, optimal polar bear

428 foraging will likely be realized when sea ice conditions allow for maximal ringed seal natality.

429 That is, a stable sea ice platform that is dynamic enough to allow seals to maintain breathing

430 holes (see Stirling 2002). 
Our results suggest polar bear foraging is variable across spatiotemporal scales and

432 intraspecific groups, possibly due to habitat-driven changes in prey availability and differences

433 in polar bear hunting ability. These results provide novel insights into the effects of sea ice

434 conditions (especially timing of break-up) on polar bear diet and body condition in regions

435 undergoing rapid reductions in sea ice. Given the projected rates of sea ice decline (Stroeve and

436 Notz 2015, Wang and Overland 2015), ongoing monitoring of the Arctic marine food web is

437 necessary for understanding species response to climatic-driven habitat changes. A better

438 understanding of the mechanistic relationships between habitat, foraging, and polar bear

439 demography is essential to predicting, and potentially managing, the effects of continued climate

440 warming on this globally vulnerable species.

\section{Acknowledgements}

442 We are particularly grateful to the Inuvialuit Game Council and the Inuvialuit hunters for

443 collecting adipose tissue samples from polar bears harvested during their annual subsistence

444 hunts. We thank Marsha Branigan and Jodie Pongracz (Government of Northwest Territories)

445 for organizing and facilitating sample collection and providing ecological insights on the

446 Beaufort Sea ecosystem. This work was supported by a Natural Sciences and Engineering

447 Research Council (NSERC) Discovery Grant to GWT, the Kenneth M. Molson Foundation,

448 Northern Scientific Training Program, and York University, Faculty of Graduate Studies. We

449 thank S. Budge and C. Barry (Dalhousie University) for conducting gas chromatography, L.

450 Harwood (Fisheries and Oceans Canada) and J. Alikamik for ringed seal adipose tissue samples,

451 and H. Stern and K. Laidre for access to sea ice data. We thank K. Rode for helpful comments on

452 an earlier draft of this manuscript. Any use of trade, firm, or product names is for descriptive

453 purposes only and does not constitute endorsement by the U.S. Government. This article was 
454 reviewed and approved under the U.S. Geological Survey, Fundamental Science Practices policy

455 (http://www.usgs.gov/fsp).

\section{Conflict of Interest}

457 The authors declare that they have no conflict of interest.

458 Statement of Animal Rights

459 The polar bear subsistence hunt and sample collection were carried out under Canadian law.

\section{References}

461 Ackman, R.G. and Eaton, C.A. 1966. Some commercial Atlantic herring oils; fatty acid 462 composition. - Fish Res. Board Canada 23: 991-1006.

463 Ashjian, C.J. et al. 2010. Climate variability, oceanography, bowhead whale distribution, and 464 Iñupiat subsistence whaling near Barrow, Alaska. - Arctic 63: 179-194.

465 Bentzen T. et al. 2007. Variation in winter diet of southern Beaufort Sea polar bears inferred 466 from stable isotope analysis. - Can. J. Zool. 85: 596-608.

467 Borcard, D. et al. 1992. Partialling out the spatial component of ecological variation. - Ecology $468 \quad 73: 1045-1055$.

469 Boucher, N. et al. 2019. Variability in polar bear Ursus maritimus stable isotopes in relation to 470 environmental change in the Canadian Beaufort Sea. -Mar. Ecol. Prog. Ser. 630: 215-225.

471 Bowen, W.D. 1997. Role of marine mammals in aquatic ecosystems. - Mar. Ecol. Prog. Ser. 158: $472 \quad 267-274$.

473 Bromaghin, J.F. et al. 2015. Polar bear population dynamics in the Southern Beaufort Sea during $474 \quad$ a period of sea ice decline. - Ecol. Appl. 25: 634-651.

475 Bromaghin, J.F. 2017. qfasar: quantitative fatty acid signature analysis with R. - Methods Ecol. $476 \quad$ Evol. 1-18. 
477 Budge, S.M. et al. 2006. Studying trophic ecology in marine ecosystems using fatty acids: A

478 primer on analysis and interpretation. - Mar. Mammal Sci. 22: 759-801.

479 Calvert, W. and Ramsay, M.A. 1998. Evaluation of age determination of polar bears by counts of $480 \quad$ cementum growth layer groups. - Ursus 10: 449-453.

481 Calvert, W. and Stirling, I. 1989. Interactions between polar bears and overwintering walruses in 482 the central Canadian High Arctic. - In: Their Biology and Management, Eigth International 483 Conference on Bear Research and Management, Victoria, British Columbia, Canada. 484 International Association for Bear Research and Management, pp. 351-356.

485 Chambellant, M. et al. 2012. Temporal variations in Hudson Bay ringed seal (Phoca hispida) 486 life-history parameters in relation to environment. - J. Mammal. 93: 267-281.

487 Cherry, S.G. et al. 2010. Quantifying dietary pathways of proteins and lipids to tissues of a 488 marine predator. - J. Appl. Ecol. 48: 373-381.

489 Derocher, A.E. et al. 2002. Diet composition of polar bears in Svalbard and the western Barents $490 \quad$ Sea. - Polar Biol. 25: 448-452.

491 Derocher, A.E. et al. 2005. Sexual dimorphism of polar bears. - J. Mammal. 86: 895-901.

492 Derocher, A.E. et al. 2010. Sexual dimorphism and the mating ecology of polar bears (Ursus 493 maritimus) at Svalbard. - Behav. Ecol. Sociobiol. 64: 939-946.

494 Durner, G.M., et al. 2017. Increased Arctic sea ice drift alters adult female polar bear movements 495 and energetics. - Glob. Chang. Biol. 23: 3460-3473.

496 Durner, G.M., Laidre, K.L., and York, G.S. (eds.) 2018. Polar Bears: Proceedings of the 18th 497 Working Meeting of the IUCN/SSC Polar Bear Specialist Group, 7-11 June 2016, 498 Anchorage, Alaska. Gland, Switzerland and Cambridge, UK: IUCN. 287 pp.

499 Ferguson, S.H. and Higdon, J.W. 2006. How seals divide up the world: Environment, life 
history, and conservation. - Oecologia 150: 318-329.

501 Ferguson, S.H. et al. 2005. Climate change and ringed seal (Phoca hispida) recruitment in 502 Western Hudson Bay. - Mar. Mammal Sci. 21: 121-135.

503 Ferguson, S.H. et al. 2017. Demographic, ecological and physiological responses of ringed seals 504 to an abrupt decline in sea ice availability. - PeerJ. doi: 10.7717/peerj.2957

Freeman, M.M.F. 1973. Polar bear predation on beluga in the Canadian Arctic. - Arctic 26: 162163.

Galicia, M.P. et al. 2016. Dietary habits of polar bears in Foxe Basin, Canada: possible evidence of a trophic regime shift mediated by a new top predator. - Ecol. Evol. 6: 6005-6018.

511 Galicia, M.P. et al. 2015. Characterization of polar bear (Ursus maritimus) diets in the Canadian High Arctic. - Polar Biol. 38: 1983-1992.

513 Hamilton, C.D. et al. 2017. An Arctic predator-prey system in flux: climate change impacts on 514 coastal space use by polar bears and ringed seals. - J. Anim. Ecol. 38: 42-49.

515 Harwood, L.A. and Kingsley, M.C.S. 2013. Trends in the offshore distribution and relative 516 abundance of Beaufort Sea belugas, 1982 - 85 vs 2007 - 09. - Arctic 66: 247-256.

517 Harwood, L.A. et al. 2014. An emerging pattern of declining growth rates in belugas of the 518 Beaufort Sea: 1989-2008. - Arctic 67: 483-492.

519 Harwood, L.A. and Smith, T.G. 2002. Whales of the Inuvialuit settlement region in Canada's $520 \quad$ Western Arctic: an overview and outlook. - Arctic 55: 77-93.

521 Harwood, L.A. et al. 2015. Seasonal movements and diving of ringed seals, Pusa hispida, in the 522 Western Canadian Arctic, 1999-2001 and 2010-11. - Arctic 68: 193-209. 
523 Harwood, L.A. et al. 2000. Variation in reproduction and body condition of the ringed seal 524 (Phoca hispida) in western Prince Albert Sound, NT, Canada, as assessed through a 525 harvest-based sampling program. - Arctic 53: 422-431.

526 Harwood, L.A. et al. 2012. Ringed seals and sea ice in Canada's western Arctic: harvest-based 527 monitoring 1992-2011. - Arctic 65: 377-390.

528 Herreman, J. and Peacock, E. 2013. Polar bear use of a persistent food subsidy: Insights from 529 non-invasive genetic sampling in Alaska. - Ursus 24: 148-163.

Higdon, J.W. and Ferguson, S.H. 2012. Environmental conditions and beluga whale entrapment events in the Husky Lakes, NWT. Canada/Inuvialuit Fisheries Joint Management Committee Report 2012. Canada/Inuvialuit Fisheries Joint Management Committee Report

534 Hornby, C. et al. 2014. Arrival of Beluga (Delphinapterus leucas) to the Mackenzie Estuary in 535 Relation to Sea Ice: Report on spring 2011-2013 aerial surveys. Freshwater Institute, $536 \quad$ Fisheries and Oceans Canada.

537 Hornby, C.A. et al. 2016. Spring conditions and habitat use of beluga whales (Delphinapterus 538 leucas) during arrival to the Mackenzie River Estuary. - Polar Biol. 39:2319-2334.

539 Hornby, C.A. et al. 2017. Beluga whale Delphinapterus leucas late summer habitat use and 540 support for foraging areas in the Canadian Beaufort Sea. - Mar. Ecol. Prog. Ser. 574: 243541257.

542 Horswill, C. et al. 2016. Unravelling the relative roles of top-down and bottom-up forces driving 543 population change in an oceanic predator. - Ecology 97: 1919-1928.

544 Huntington, H.P. 2002. Traditional knowledge of the ecology of belugas, Delphinapterus leucas, 545 in Cook Inlet, Alaska. - Mar. Fish. Rev. 62: 134-140. 
Huntington, H.P. et al. 1999. Traditional Knowledge of the ecology of beluga whales

(Delphinapterus lencas) in the Eastern Chukchi and Northern Bering Seas, Alaska. - Arctic 52: 49-61.

Iverson, S.J. et al. 2004. Quantitative fatty acid signature analysis: A new method of estimating predator diets. - Ecol. Monogr. 74: 211-235.

Katona, S. and Whitehead, H. 1988. Are Cetacea ecologically important? - Oceanogr. Mar. Biol. Annu. Rev. 26: 553-568.

Kingsley, M.C.S. et al. 1985. The distribution and abundance of seals in the Canadian high Arctic. - Can. J. Fish. Aquat. Sci. 42: 1189-1210.

Legendre, P. and Gallagher, E.D. 2001. Ecologically meaningful transformations for ordination of species data. - Oecologia 129: 271-280.

Lillie, K. et al. 2019. Use of subsistence-harvested whale carcasses by polar bears in the Southern Beaufort Sea. -Arctic 72: 404-412.

Lindsay, R. and Schweiger, A. 2015. Arctic sea ice thickness loss determined using subsurface, aircraft, and satellite observations. - Cryosph. 9: 269-283.

Lone, K. et al. 2018. Sea ice resource selection models for polar bears in the Barents Sea subpopulation. - Ecography 41: 567-578.

Lunn, N.J. et al. 2016. Demography of an apex predator at the edge of its range - impacts of changing sea ice on polar bears in Hudson Bay. - Ecol. Appl. 26: 1302-1320.

Luque, S.P. and Ferguson, S.H. 2009. Ecosystem regime shifts have not affected growth and survivorship of eastern Beaufort Sea belugas. - Oecologia 160: 367-378.

Maslanik, J. et al. 2011. Distribution and trends in Arctic sea ice age through spring 2011. Geophys. Res. Lett. 38: 2-7. 
McKinney, M.A. et al. 2017. Temporal complexity of southern Beaufort Sea polar bear diets during a period of increasing land use. - Ecosphere 8: doi: 10.1002/ecs2.1633

McKinney, M.A., et al. 2014. Validation of adipose lipid content as a body condition index for polar bears. - Ecol. Evol. 4: 516-527.

Obbard, M.E. et al. 2016. Trends in body condition in polar bears (Ursus maritimus) from the Southern Hudson Bay subpopulation in relation to changes in sea ice. - Arct. Sci. 2: 15-32.

Parmesan, C. 2006. Ecological and Evolutionary Responses to Recent Climate Change. - Annu. Rev. Ecol. Evol. Syst. 37: 637-669.

Peacock, E. et al. 2012. The utility of harvest recoveries of marked individuals to assess polar

Pickart, R.S. et al. 2013. Long-term trends of upwelling and impacts on primary productivity in the Alaskan Beaufort Sea. - Deep Sea Res. Part I Oceanogr. Res. Pap. 79: 106-121.

Pilfold, N.W. et al. 2015. Multi-temporal factors influence predation for polar bears in a changing climate. - Oikos 124: 1098-1107.

Pilfold, N.W. et al. 2014. Polar bear predatory behaviour reveals seascape distribution of ringed seal lairs. - Popul. Ecol. 56: 129-138.

Pond, C.M. 1992. An evolutionary and functional view of mammalian adipose tissue. - Proc. Nutr. Soc. 51: 367-377.

Quakenbush, L. et al. 2011. Biology of the bearded seal (Erignathus barbatus) in Alaska, 19612009. Final Report to: National Marine Fisheries Service.

Regehr, E.V. et al. 2016. Conservation status of polar bears (Ursus maritimus) in relation to projected sea-ice declines. - Biol. Lett. 12: 20160556.

591 Regehr, E.V. et al. 2007. Effects of earlier sea ice breakup on survival and population size of 
polar bears in Western Hudson Bay. - J. Wildl. Manage. 71: 2673-2683.

593 Reimer, J.R. et al. 2019. Ringed seal demography in a changing climate. -Ecol. Appl. 29.3:

$594 \quad \mathrm{e} 01855$.

595 Rode, K.D. et al. 2010. Reduced body size and cub recruitment in polar bears associated with sea 596 ice decline. - Ecol. Appl. 20: 768-782.

597 Rode, K.D. et al. 2014. Variation in the response of an Arctic top predator experiencing habitat 598 loss: Feeding and reproductive ecology of two polar bear populations. - Glob. Chang. Biol. $59920: 76-88$.

600 Schliebe, S. et al. 2008. Effects of sea ice extent and food availability on spatial and temporal 601 distribution of polar bears during the fall open-water period in the Southern Beaufort Sea. 602 Polar Biol. 31: 999-1010.

603 Schulze, L.M. and Pickart, R.S. 2012. Seasonal variation of upwelling in the Alaskan Beaufort 604 Sea: Impact of sea ice cover. - J. Geophys. Res. Ocean. doi: 10.1029/2012JC007985

605 Sciullo, L. et al. 2016. Comparative assessment of metrics for monitoring the body condition of 606 polar bears in western Hudson Bay. - J. Zool. 300: 45-58.

607 Smith, T.G. 1980. Polar bear predation of ringed and bearded seals in the land-fast sea ice 608 habitat. - Can. J. Zool. 58: 2201-2209.

609 Smith, T.G. and Sjare, B. 1990. Predation of belugas and narwhals by polar bears in nearshore 610 areas of the Canadian High Arctic. - Arctic 43: 99-102.

611 Smith, T.G. and Stirling, I. 1975. The breeding habitat of the ringed seal (Phoca hispida). The 612 birth lair and associated structures. - Can. J. Zool. 53: 1297-1305.

613 Stern, H.L. and Laidre, K.L. 2016. Sea-ice indicators of polar bear habitat. - Cryosph. 10: 2027614 2041. 
615 Stirling, I. 2002. Polar bears and seals in the eastern Beaufort Sea and Amundsen Gulf: A

616 synthesis of population trends and ecological relationships over three decades. - Arctic 55:

$617 \quad 59-76$.

618 Stirling, I. and Derocher, A.E. 1993. Possible impacts of climatic warming on polar bears. -

619 Arctic 46: 240-245.

620 Stirling, I. et al. 1999. Long-term trends in the population ecology of polar bears in western

621 Hudson Bay in relation to climatic change. - Arctic 52: 294-306.

622 Stirling, I. et al. 2011. Polar bear population status in the northern Beaufort Sea, Canada, 1971623 2006. - Ecol. Appl. 21: 859-876.

624 Stirling, I. and Oritsland, N.A. 1995. Relationships between estimates of ringed seal (Phoca 625 hispida) and polar bear (Ursus maritimus) populations in the Canadian Arctic. - Can. J.

626 Fish. Aquat. Sci. 52: 2594-2612.

627 Stroeve, J. and Notz, D. 2015. Insights on past and future sea-ice evolution from combining

628 observations and models. - Glob. Planet. Change 135: 119-132.

629 Stroeve, J.C. et al. 2012. Trends in Arctic sea ice extent from CMIP5, CMIP3 and observations. $630 \quad$ Geophys. Res. Lett. 39:1-7.

631 Thiemann, G.W. et al. 2004. Determining blubber fatty acid composition: a comparison of in situ 632 direct and traditional methods. - Mar. Mammal Sci. 20: 284-295.

633 Thiemann, G.W. et al. 2007. Unusual fatty acid biomarkers reveal age- and sex-specific foraging 634 in polar bears (Ursus maritimus). - Can. J. Zool. 85: 505-517.

635 Thiemann, G.W. et al. 2006. Seasonal, sexual and anatomical variability in the adipose tissue of 636 polar bears (Ursus maritimus). - J. Zool. 269: 65-76.

637 Thiemann, G.W. et al. 2008a. Polar bear diets and Arctic marine food webs: Insights from fatty 
acid analysis. - Ecol. Monogr. 78: 591-613.

639 Thiemann, G.W. et al. 2008b. Variation in blubber fatty acid composition among marine

640 mammals in the Canadian Arctic. - Mar. Mammal Sci. 24: 91-111.

641 Togunov, R.R. et al. 2017. Windscapes and olfactory foraging in a large carnivore. - Sci. Rep. 7:

64246332.

643 van den Wollenberg, A.L. 1977. Redundancy analysis an alternative for canonical correlation $644 \quad$ analysis. - Psychometrika 42: 207-219.

645 Wang, M. and Overland, J.E. 2015. Projected Future Duration of the Sea-Ice-Free Season in the 646 Alaskan Arctic. - Prog. Oceanogr. 136: 50-59.

647 Wassmann, P. et al. 2011. Footprints of climate change in the Arctic marine ecosystem. - Glob.

$648 \quad$ Chang. Biol. 17: 1235-1249.

649 Wood, K.R. et al. 2013. Is there a "new normal" climate in the Beaufort Sea? - Polar Res. 32:

$650 \quad 19552$.

651 Young, B.G. et al. 2015. Variation in ringed seal density and abundance in western Hudson Bay 652 estimated from aerial surveys, 1995 to 2013. - Arctic 68: 301-309.

653 Yurkowski, D. et al. 2016. Influence of sea ice phenology on the movement ecology of ringed 654 seals across their latitudinal range. - Mar. Ecol. Prog. Ser. 562: 237-250.

655

656 


\section{Figure Captions}

658 Figure 1 Locations of polar bears (red circle) harvested in the Beaufort Sea from 1999 to 2015. 659 Bears were located in the boundaries of the Southern Beaufort Sea (SB) or the Northern Beaufort 660 Sea (NB) subpopulation.

661 Figure 2 Effect of age on estimated contribution (mean \pm SE) of ringed seal and bearded seal in 662 the diet of male polar bears in the Canadian Beaufort Sea (1999-2015). Results from Spearman

663 rank correlation shown on figure with 95\% confidence intervals (grey shading).

664 Figure 3 Seasonal diet composition (mean \pm SE) of polar bears in the Beaufort Sea, 1999 to 665 2015, as estimated from QFASA. Winter/spring is defined as January-June and summer/fall as 666 July-December.

667 Figure 4 Temporal trends in polar bear diet composition (mean \pm SE) and body condition (\% 668 lipid content in adipose tissue; mean $\pm \mathrm{SE}$; dotted line) of polar bears in the Beaufort Sea.

669 Figure 5 Temporal trends in sea ice in the Northern and Southern Beaufort Sea polar bear 670 subpopulations. Statistical results from linear regression are shown on the figure with $95 \%$ 671 confidence intervals (grey shading). Data from Stern and Laidre 2016.

672 Figure 6 Effects of sea ice break-up (ordinal date; data from Stern and Laidre 2016) on 673 proportional contribution (mean \pm SE) of beluga whale to the diets of female polar bears in the 674 Northern Beaufort Sea (2003-2014). Statistical results from linear regression are shown on the 675 figure with 95\% confidence intervals (grey shading).

676 Figure 7 The effect of sea ice conditions on body condition (mean \pm SE) of female polar bears in 677 the Northern Beaufort Sea subpopulation (1999-2015). Statistical results from linear regression 678 are shown on the figure with $95 \%$ confidence intervals (grey shading). Data from Stern and 679 Laidre 2016. 


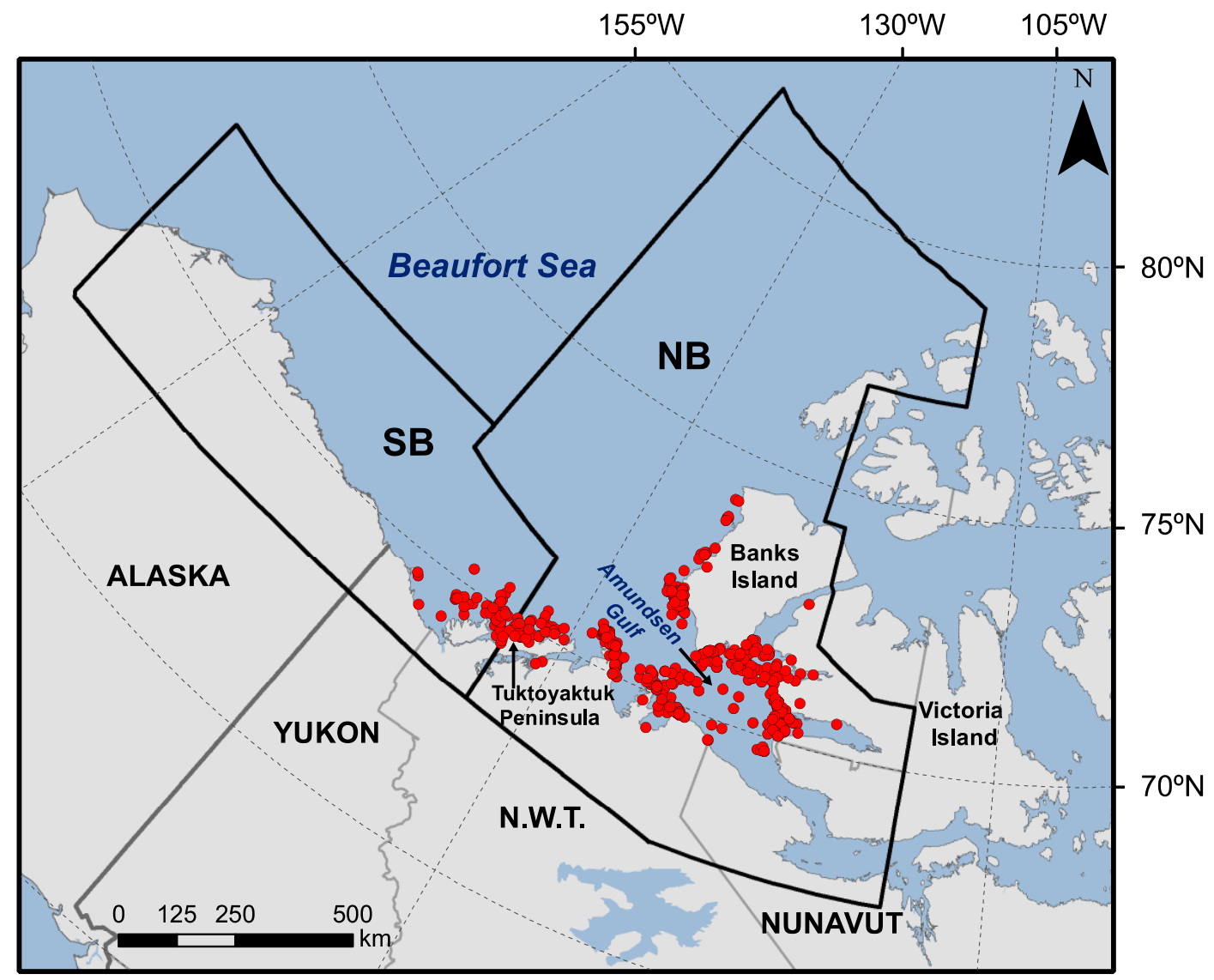

Figure 1 


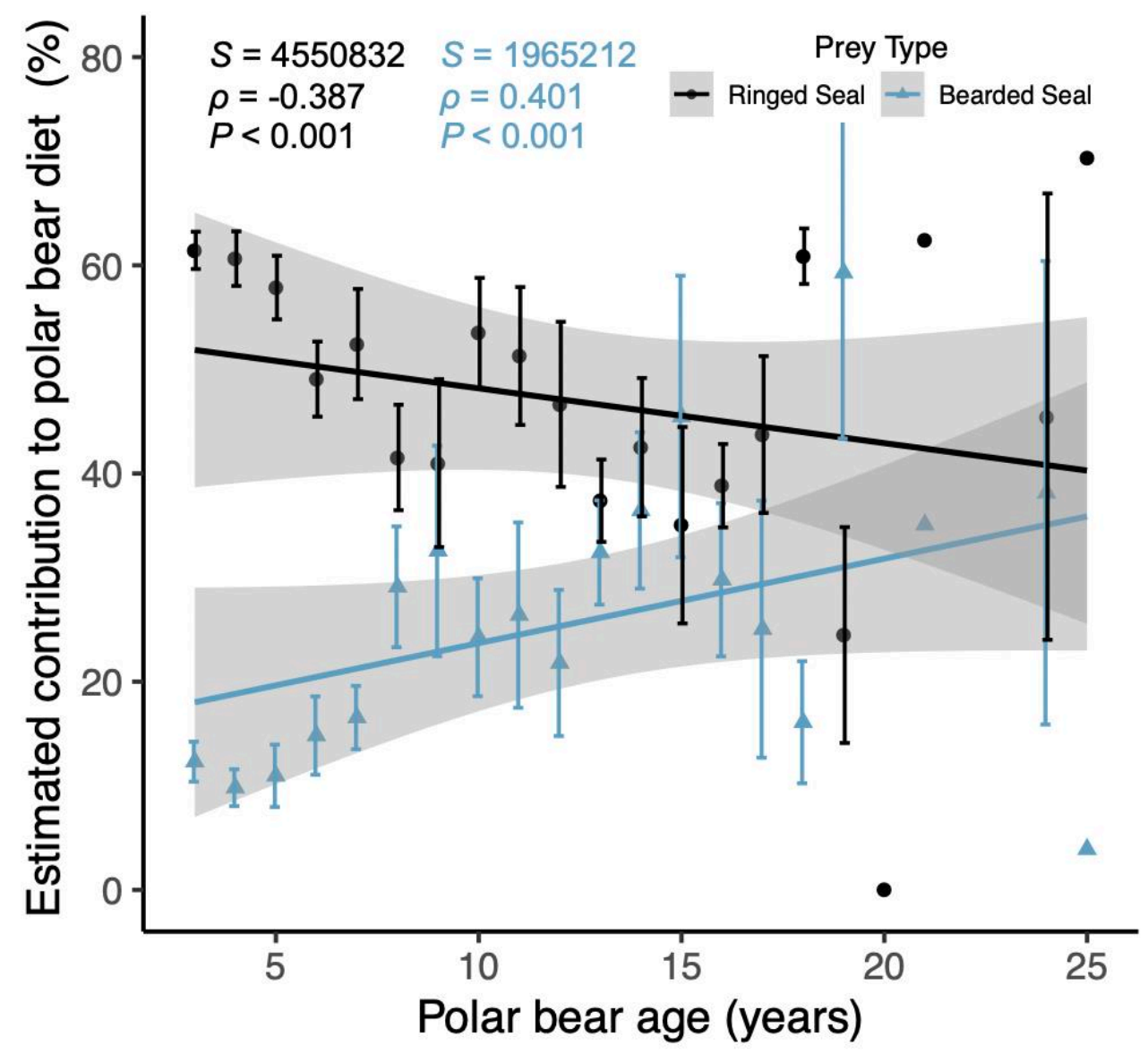

Prey Type $\rightarrow$ Ringed Seal $\rightarrow$ Bearded Seal

Figure 2 


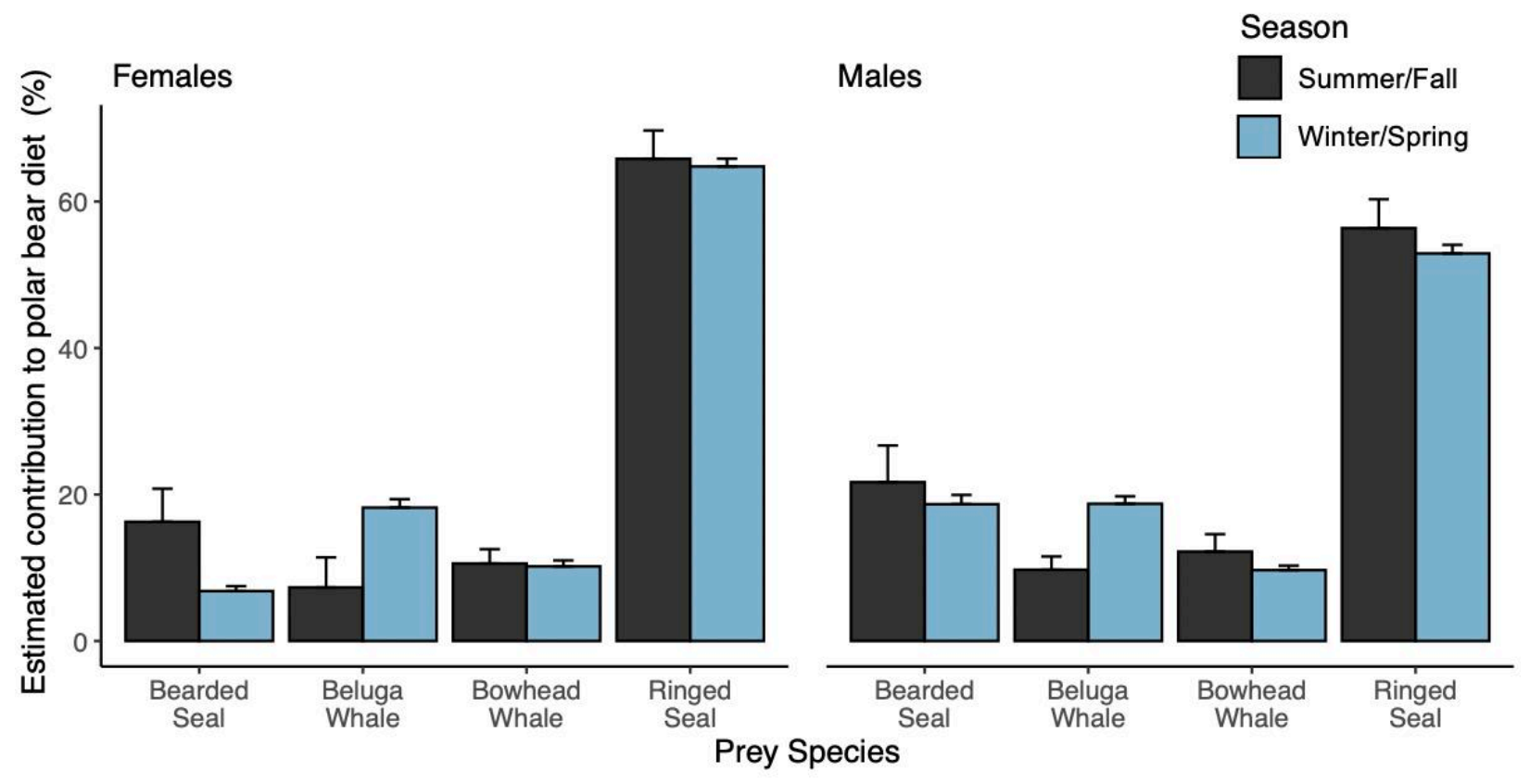

Figure 3 


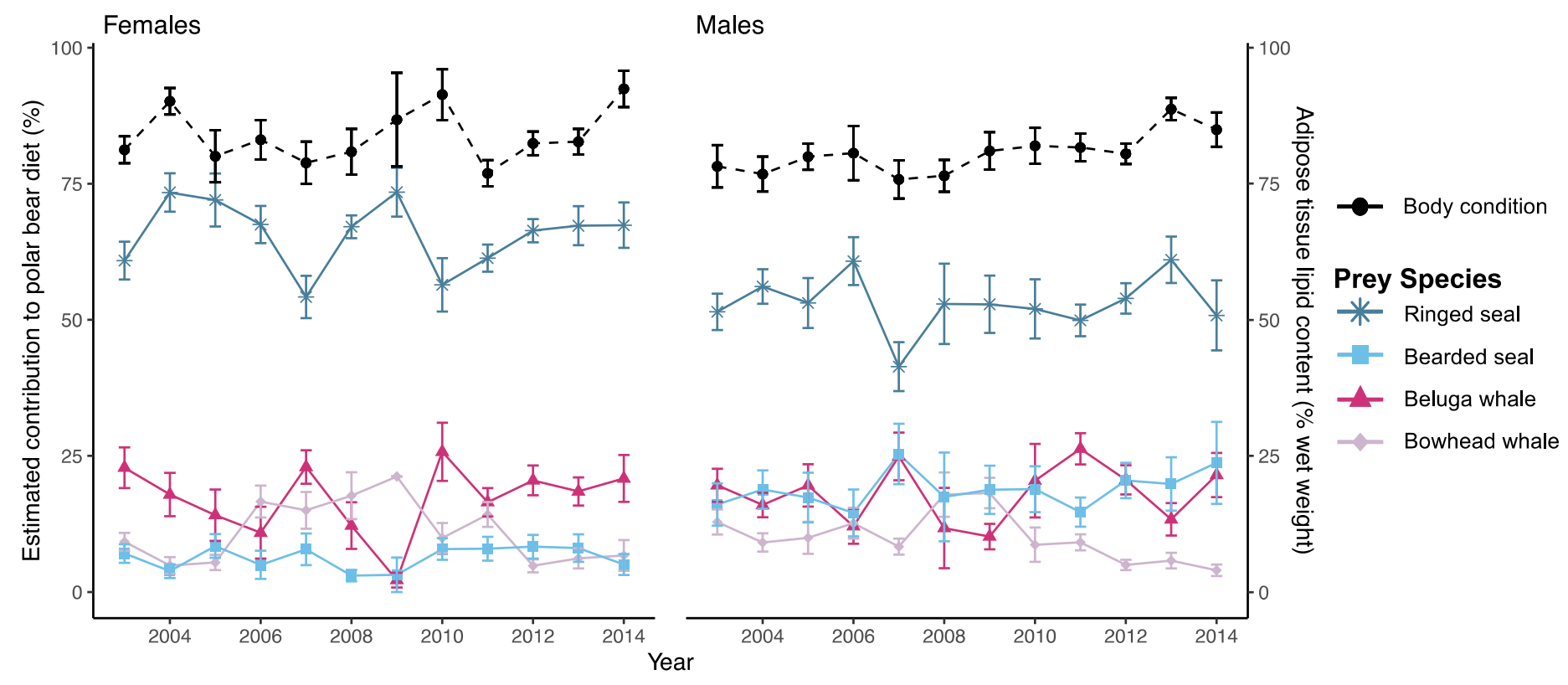

Figure 4 

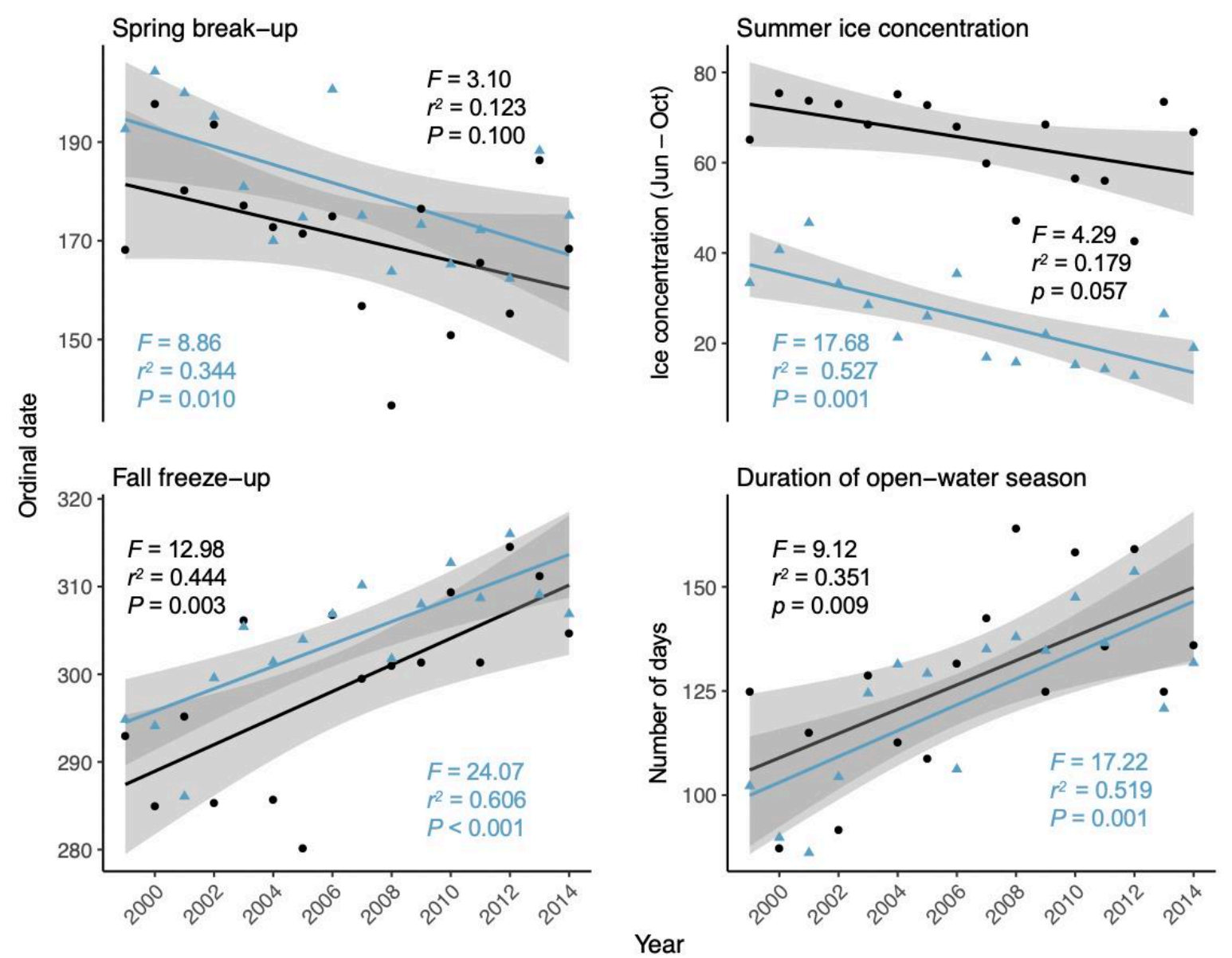

Subpopulation $\rightarrow$ Northern Beaufort Sea

Southern Beaufort Sea

\section{Figure 5}




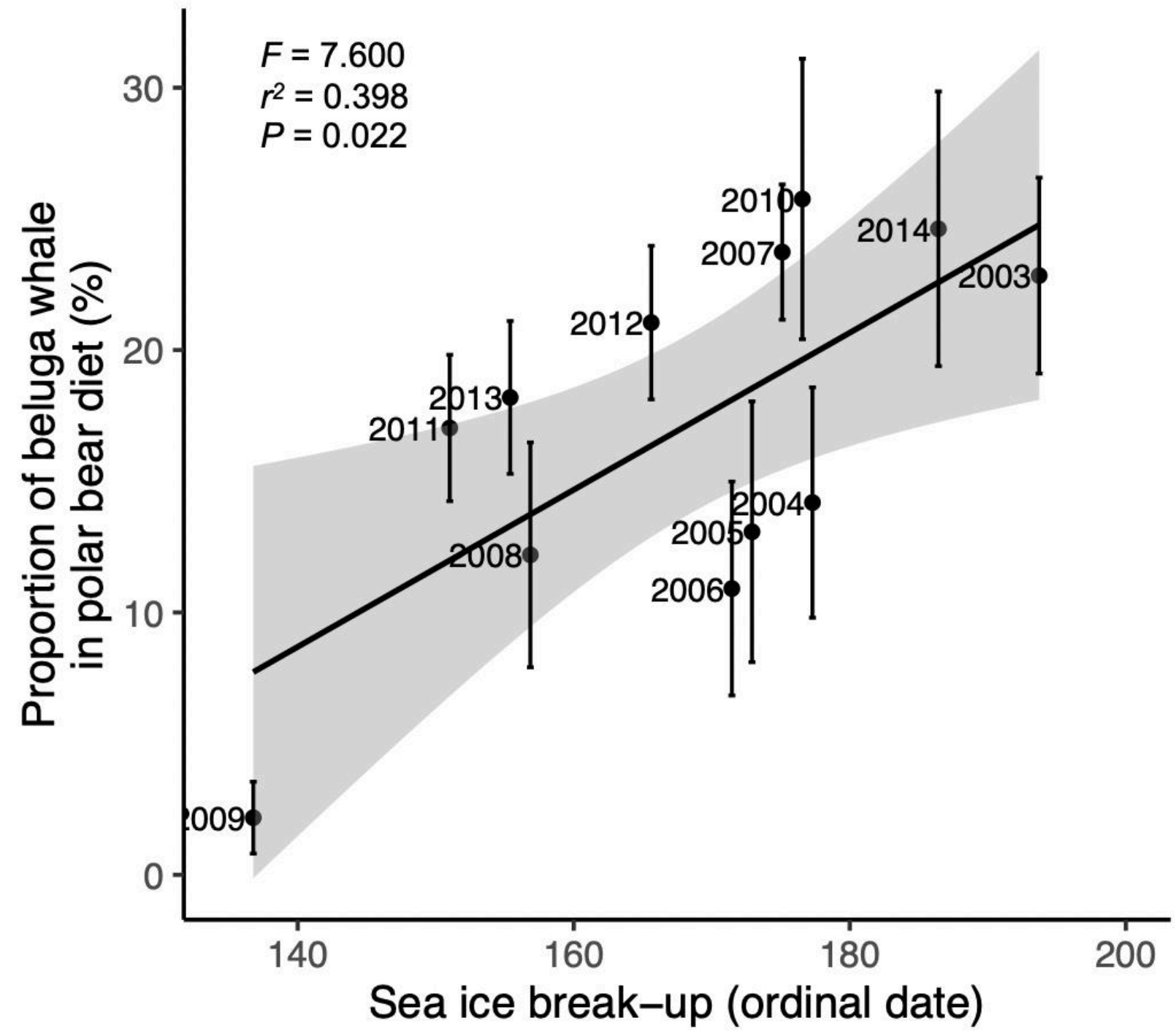

Figure 6 

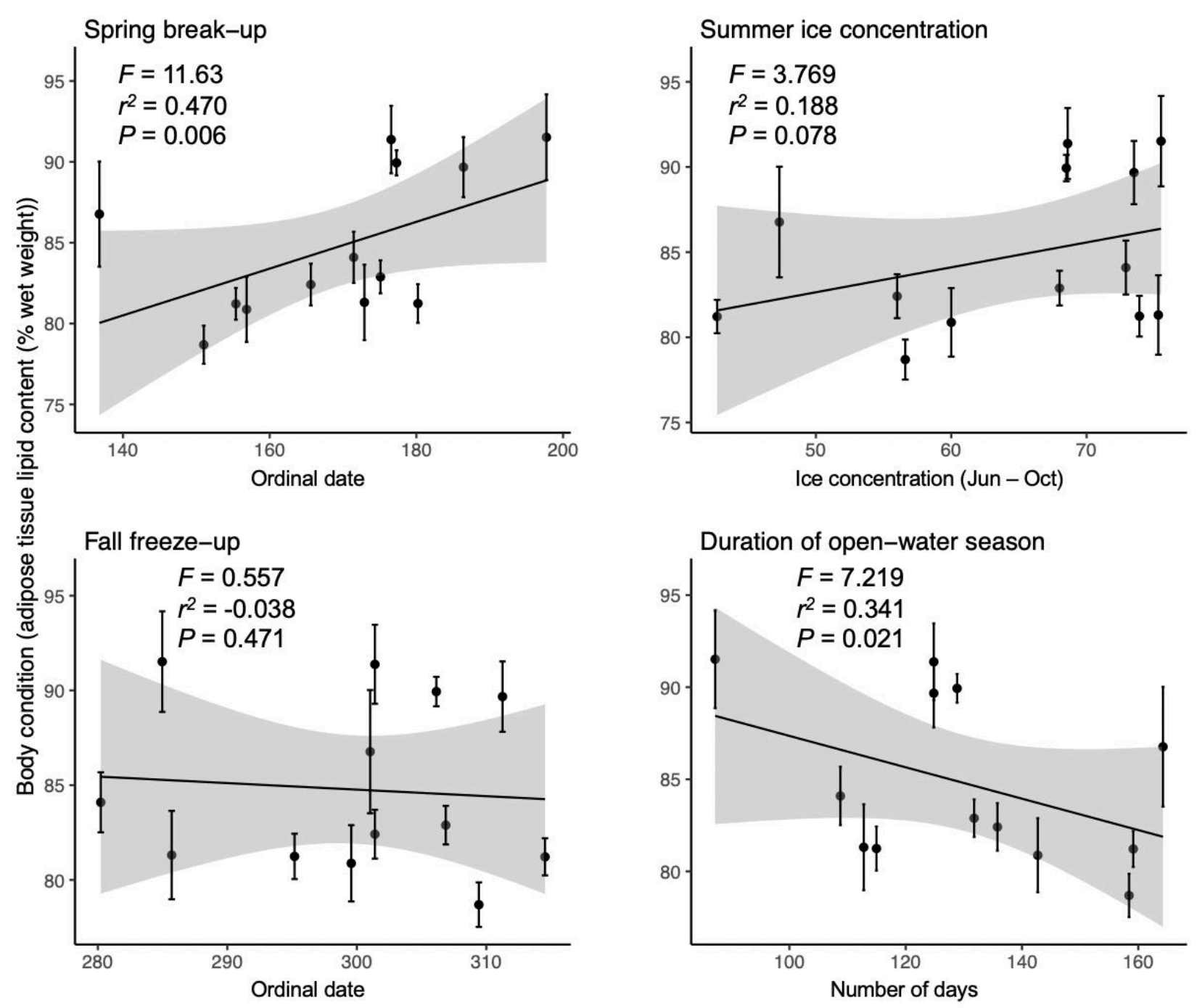

Figure 7 
Table 1 Redundancy analysis (RDA) candidate models evaluating the best-fitting model of factors influencing the diet of polar bears in the Canadian Beaufort Sea from 1999 to 2015. Akaike Information Criterion (AIC) was used as the main criteria for model selection. Variables: long = longitude; sif = date of sea ice freeze-up; sib = date of sea ice break-up.

\begin{tabular}{lccccc}
\hline \multirow{2}{*}{ Model } & \multicolumn{5}{c}{ RDA forward-selection model } \\
\cline { 2 - 6 } & $\mathrm{AIC}$ & $\Delta \mathrm{AIC}$ & $w$ & $\mathrm{~F}$ & $p$-value \\
\hline long & -812.03 & 40.97 & $<0.001$ & 21.108 & 0.002 \\
long + sex & -828.98 & 24.02 & $<0.001$ & 19.259 & 0.002 \\
long + sex + age & -841.71 & 11.29 & 0.003 & 14.849 & 0.002 \\
long + sex + age + sif & -845.48 & 7.52 & 0.018 & 5.741 & 0.006 \\
long + sex + age + sif + sib & -850.54 & 2.46 & 0.222 & 7.020 & 0.002 \\
long + sex + age + sif + sib + year & -853.00 & 0 & 0.758 & 4.408 & 0.006 \\
\hline
\end{tabular}

